\title{
Results of more than 20 years of follow- up in pediatric patients with moyamoya disease undergoing pial synangiosis
}

TO THE READERSHIP: An error appeared in the article by Riordan et al. (Riordan CP, Storey A, Cote DJ, et al: Results of more than 20 years of follow-up in pediatric patients with moyamoya disease undergoing pial synangiosis. J Neurosurg Pediatr [epub ahead of print March 1, 2019; DOI: 10.3171/2019.1.PEDS18457]).

In the second sentence of the Conclusions section of the Abstract, the number of patients was incorrectly stated as "5." The corrected sentence appears below.

A history of cranial radiation was present in 4 of the 6 patients who died and in the lone patient with late stroke.

The article has been corrected online as of May 3,2019.

Edward R. Smith, MD Boston Children's Hospital, Boston, MA

\section{INCLUDE WHEN CITING}

Published online May 3, 2019; DOI: 10.3171/2019.4.PEDS18457a.

CAANS 2019, except where prohibited by US copyright law 